\title{
EARNINGS, UNEMPLOYMENT, AND HOUSING IN BRITAIN
}

\author{
GAVIN CAMERON ${ }^{\mathrm{a}}$ AND JOHN MUELLBAUER ${ }^{\mathrm{b} *}$ \\ a Department of Economics, Oxford University, $U K$ \\ b Nuffield College, Oxford, UK
}

\section{SUMMARY}

This paper models regional earnings and unemployment in the ten regions of Great Britain between 1972 and 1995, paying particular attention to their interaction and to the important influence of the housing market. In contrast to Blanchard and Katz $(1992,1997)$ for the United States, we find less persistence in British regional earnings differentials but greater persistence in regional unemployment rates. We find no evidence of a negative effect of the overall unemployment rate on the earnings of men in non-manual, or women in fulltime, employment. However, for manual men, we find a significant elasticity of around -0.07 , comparable with Blanchflower and Oswald (1994). Copyright (c) 2001 John Wiley \& Sons, Ltd.

\section{INTRODUCTION}

This paper has four main aims. The first is to use regional data to illuminate classic debates about the relationship between unemployment and earnings, which concerned Dennis Sargan himself (Sargan, 1964, 1971, 1980); as well as Layard, Nickell and Jackman (1991) and the new twists given to the issue by Blanchflower and Oswald (1994). The latter argue that a 'wage curve' exists, implying a negative relationship between unemployment and real wages which is fairly stable over time and between countries.

The use of regional earnings and unemployment differentials has important advantages in removing difficult-to-model national features of the data, such as national expectations of prices and changes in national legislation. For example, it is likely that regional differentials are less contaminated by the effect of equal pay legislation, incomes policies, and the many industrial and labour market reforms of the Thatcher era. When the effects of structural changes have a homogenous additive effect on the variables of interest, we have a simple example of 'co-breaking', a concept introduced by Hendry (1997). Co-breaking occurs when a linear combination of variables subject to a structural break removes the effect of that break. A less attractive aspect is that models of regional earnings differentials can have little to say about the relevant macrovariables entering national wages and salary negotiations. This limits the conclusions which can be drawn on the macroeconomics of pay determination.

Second, the paper explores the interactions of labour and housing markets in the determination of earnings and unemployment outcomes. The mechanisms at work include, in principle, the influence of housing tenure on labour mobility and migration ${ }^{1}$, the effect of house prices on migration, commuting and firm location, and hence on regional mismatch ${ }^{2}$, the effects of

* Correspondence to: Professor J. Muellbauer, Nuffield College, Oxford, OXI INF.

E-mail: John.Muellbauer@economics.ox.ac.uk

Contract/grant sponsor: ESRC; Contract/grant number: R00023 7500.

${ }^{1}$ See, for example, Hughes and McCormick (1987), Minford, Peel and Ashton (1987) and McCormick (1997).

${ }^{2}$ See Jackman and Savouri (1992) and Cameron and Muellbauer (1998). 
house prices on the cost of living, on the demand side via wealth effects and perhaps on expectations ${ }^{3}$.

Our third aim is to derive explicit one-year-ahead forecasting models. Such models have multiple uses, including the derivation of efficient instruments for modelling regional variables such as consumption and house prices. Our fourth aim is to examine the regional incidence of monetary policy. This works through both interest rates and the exchange rate, as well as more indirectly through house prices.

The plan of the paper is as follows. Section 2 reviews the theoretical background. Section 3 considers regional labour market data issues and discusses our econometric method. This paper estimates models using both a dynamic fixed effects estimator (based on Generalized Least Squares, which allows error variances to differ across groups) and also the Pesaran, Shin and Smith (1999) Pooled Mean Group estimator. Section 4 presents our models of earnings and unemployment for a panel of British regions. Section 5 draws conclusions. The Data Appendix reviews the sources of the data used in the paper.

\section{BACKGROUND}

The work of Phillips (1958) stimulated a great deal of research on the connection between nominal wage inflation and unemployment. Apart from its many important contributions to econometric methodology, the paper by Sargan (1964) anticipates the later literature on the expectations-augmented Phillips curve by emphasizing that, in the long run, workers and firms should be concerned with real wages (see Phelps, 1968; Friedman, 1968). Sargan therefore posits an equilibrium correction model where the rate of change of nominal wages depends on the lagged rates of changes of prices, on the lagged real wage, on the lagged unemployment rate and on shifting trends reflecting productivity, government policy and union power. Indeed, Sargan emphasizes the long-run solution for the real wage. Such a model can be trivially re-parameterised ${ }^{4}$ into a real wage model of the type that Layard and Nickell (1986) estimate for the UK, and that Layard, Nickell and Jackman (1991, Chapter 9), estimate for the OECD countries. These authors include further terms such as the long-term unemployment rate, proxies for union power and labour market mismatch, components of the 'wedge' between product prices relevant for firms and consumer prices relevant for workers, and the replacement rate.

The work of Layard and Nickell gives good grounds for supposing that unemployment has a negative effect on wages at the aggregate level. At the regional level, a compensating differentials argument suggests the opposite: high wages may be necessary to compensate for high unemployment. In the influential model of Harris and Todaro (1970), which comprises a developed urban and undeveloped rural sector, a migration equilibrium is achieved through unemployment in the developed urban sector. Of course, while high wages may serve to compensate for higher unemployment, in a developed economy they might just be compensating for some other factor, such as high housing costs, labour quality differences, differences in private or public capital per worker, or lack of regional amenity.

The evidence is mixed. For the United States, it appears that high wage states tend to have higher unemployment rates (see Blanchard and Katz, 1992; Hall, 1970). In contrast, Blanchflower

\footnotetext{
${ }^{3}$ See Bover, Muellbauer and Murphy (1989) and McCormick (1997).

${ }^{4} \mathrm{By}$ adding a term in the rate of change of current inflation. 
and Oswald (1994, 1995) claim to find an empirical regularity (the 'wage curve') of a robust negative correlation between wages and log unemployment for a wide range of different countries and datasets, with a typical elasticity of around -0.10 . Their approach is to use repeated crosssections of data on individuals in a range of countries. They argue therefore that employees in areas of high unemployment earn lower wages, other things being equal, than those in low unemployment areas 5 . However, as Card (1995) notes, the wage curve may be very different for different groups of workers. In general, younger, less well-educated, less unionized, men are more likely to have a significant unemployment elasticity of pay. Blanchflower and Oswald also challenge the orthodoxy of the Phillips curve by suggesting that dynamics are unimportant in the wage equation and conclude that once region and time effects are included, there is "little sign of autoregression in wage equations' (1994, p. 284).

For the United States, it has been argued that most of the regional adjustment to shocks is through movements of labour rather than through job creation or job migration (see Blanchard and Katz, 1992). For the United Kingdom, many commentators have suggested that movements of labour play only a small role in regional adjustment. For example, McCormick (1997) suggests that differences in UK regional unemployment rates show little sign of disappearing and that this is exacerbated by low levels of migration among manual workers. Jackman and Savouri (1992) argue that it is also important to examine regional commuting, since this enables workers to change their jobs without changing their home.

This leads naturally to the role of housing market influences neglected in almost all the literature on national wages and unemployment as well as much of the regional literature (e.g. Blanchard and Katz, 1992, 1997; Jackman, Layard and Savouri, 1991; Blanchflower and Oswald, 1994, 1995; Pissarides and McMaster, 1990) ${ }^{6}$.

Bover et al. (1989) argue that there are as many as five potential housing market channels of influence on national wages and unemployment. The first is the effect of housing tenure on mobility rates, which is likely to affect regional labour mismatch. In the UK, even after correction for individual, occupational and local characteristics, the highest mobility rates are for individuals in the private rented sector, especially after abolition of rent controls. The lowest rates are for those resident in public housing, particularly when rents are far below market levels, while those in owner-occupation have intermediate mobility rates (see Hughes and McCormick, 1987, 2000). The second is the cost of living effect on workers already in the region and also on potential migrants from house and, indirectly, land prices ${ }^{7}$. The third is the cost of location effect from land prices on firms in the region and potential movers to the region. The fourth is a wealth effect on regional spending, in part via the collateral role of housing equity on credit-constrained households and small businesses. The fifth is an expectations effect in that future movements of earnings may be capitalized in house and land prices.

For models of British regional earnings and unemployment differentials, much of the first channel is likely to wash out since changes in tenure structure tend to be national, e.g. the removal

\footnotetext{
${ }^{5}$ Note that this conclusion is only strictly true in models with no regional fixed effects. If regional fixed effects are included, the models cannot be interpreted as saying anything about the absolute level of wages. Instead, it is more relevant to say that other things being equal, when unemployment rises in a region, wages fall (Bell, 1997).

${ }^{6}$ Blanchard and Katz (1992) acknowledge the potential relevance of land prices, (p. 24) but confine empirical analysis to a briefly summarized bivariate model of employment and house prices (p. 45).

7 This can give rise to temporarily high regional labour market mismatch associated with temporarily high house price differentials relative to earnings differentials, which constrain net migration to booming regions such as the South East of England in the 1980s. The evidence in Cameron and Muellbauer (1998) is for large relative house price effects in Britain on net interregional migration rates, given earnings and unemployment differentials.
} 
of rent controls, the sale of public housing, the rise of owner-occupation. Moreover, while at the national level, higher proportions of market rented housing should be associated with greater mobility and lower average unemployment, this is far from obvious at the regional level. Suppose that in the South East unemployment is unusually low and house prices unusually high, the latter encouraging out-migration and tending to block in-migration of the credit constrained into owner-occupation. A larger market rented sector in the South East will remove some of the inmigration blocks and so bring down unemployment rates in the other regions. It is therefore far from clear that within a region there will be a negative association between the tenure proportion in the market rented sector (or a positive association with the owner-occupation rate $^{8}$ ) and the unemployment rate.

The remaining four channels could all, however, be manifested in relative house price effects on regional earnings and unemployment differentials. The cost of living, wealth and expectations channels imply positive effects on relative earnings from lagged relative house prices, while the cost of location effect partly offsets these. For relative unemployment, the forces are more evenly balanced. The cost of living effect of relative house prices on higher future relative earnings is likely to repel firms but credit-constrained potential migrants are also likely to be repelled, leaving the effect on relative unemployment rates ambiguous ${ }^{9}$. The cost of location effect pushes up relative unemployment while the wealth effect is in the reverse. The expectations channel is ambiguous since labour costs and profit expectations have opposite effects on firms' location decisions.

At any rate, it is clear that the relative earnings, employment and unemployment system considered by Blanchard and Katz (1992, p. 21) needs considerable extension. Relative house prices should enter all four equations: the labour demand equation, the 'wage curve', the labour force growth equation (largely migration) and the equation governing the evolution of regional demand function intercepts. To complete the new system, two more equations are needed, one for relative house prices (see Muellbauer and Murphy, 1994, for one specification) and one for relative housing stocks, since these are significant determinants of relative house prices. In what follows, we model only relative earnings and relative unemployment rates in a broadly conceived subset of a VAR system. However, another difference from Blanchard and Katz and other previous work is that we make explicit the channels by which key macroeconomic variables have distinct regional impacts.

\section{ECONOMETRIC METHOD}

In this following section we estimate models of relative regional log earnings (taken from the New Earnings Survey, see Data Appendix for details, and Cameron and Muellbauer (2000) for discussion of regional data problems) for two types of workers and relative regional unemployment

\footnotetext{
${ }^{8}$ Oswald (1998) has recently argued that high levels of home-ownership and the collapse of the private rented sector in the UK has led to higher structural unemployment. Using data from the British Social Attitudes Survey between 1983 and 1994, he finds that home-owners are generally less willing to move to a different area to find a job, other things being equal. Furthermore, there does appear to be a correlation between home-ownership and unemployment at a cross-country level. Oswald's startling analysis of nineteen OECD countries concludes that the rise in home-ownership in the UK since the 1960 s added around 4 percentage points to the UK unemployment rate.

${ }^{9}$ In practice, the migration effect is likely to be small since we know that migration rates are lowest among manual workers (see Hughes and McCormick, 1987), who in the 1980s and 1990s, according to the Labour Force Survey, have had unemployment rates twice as high as non-manuals, with even greater discrepancies for men.
} 
rates using data for 1972 to 1995 for the ten regions of Great Britain. The models take the following general form ${ }^{10}$ :

$$
\Delta y_{i t}=\alpha\left(\theta_{i}+\sum_{j=1}^{k} \beta_{j} x_{j i t-1}-y_{i t-1}\right)+\sum_{s=1}^{m} \gamma_{s} \Delta y_{i t-s}+\sum_{s=1}^{m} \sum_{j=1}^{k} \gamma_{j s} \Delta x_{j i t-s}+\varepsilon_{i t}
$$

Thus, the long-run solution has the form

$$
y_{i t}=\theta_{i}+\sum_{j=1}^{k} \beta_{j} x_{j i t}+\eta_{i t}
$$

where the three $y$ variables are, respectively, relative log-earnings for full-time men and women ${ }^{11}$, and the unemployment rate in each region minus the rate in Great Britain. We assume that the disturbance terms, $\varepsilon_{i t}$, are distributed independently across groups and time and that $\eta_{i t}$ is a stationary process (see Pesaran, Shin and Smith, 1999). For each $y$ variable, the $x$ variables include the relevant complementary elements of the other two $y$ variables; relative house prices weighted by lagged owner-occupation in the UK for the earnings equations and unweighted for the unemployment equation; the relative proportion of employment in the production sector and its interaction with the log real exchange rate; the relative proportion of employment in banking and financial services and its interactions with bank base rate, a proxy for financial liberalization, and real UK house prices; the relative proportion of women in part-time employment; and the relative proportion of manual workers. The $x$ variables also include interactions between the relative mortgage debt to earnings ratio with the average mortgage interest rate. All the $x$ variables test as being $\mathrm{I}(1)$ in levels and $\mathrm{I}(0)$ in differences using the panel unit root test suggested by Im, Pesaran and Shin (1997), as do the $y$ variables, (see the Data Appendix).

Two features of the $\Delta x$ variables should be noted. Where $x_{j i t-1}$ appears in the form $w_{i t-1} x_{j i t-1}^{*}$, where $w_{i t-1}$ is a regional weight and $\sum_{i} w_{i t-1}=0, \Delta x_{j i t-s}$ actually denotes $w_{i t-1} \Delta x_{j i t-s}^{*}$. Otherwise $\Delta x_{j i t-s}$ has the conventional meaning. Second, given the sophistication of the banking and financial services sector and its sensitivity to interest rates, the set of $\Delta x$ variables includes last year's expectation of the contemporaneous change in bank base rate, weighted by the regional deviation of the sector's lagged employment share.

The maximum lag considered in all four equations was $m=2$ and 'general to simple' testing procedures were used to select parsimonious specifications. The estimation technique is twostep GLS using the 'seemingly unrelated regression' option in the Hall et al. (1995) Time Series Processor (TSP) for the first step (see Zellner, 1962), computing the covariance matrix of residuals across the ten regions and fixing this for GLS at the second step. Where relevant, the covariance matrix is also corrected for instrumented contemporaneous effects. Where $F$-tests are reported these hold constant the covariance matrix of the null hypothesis against the more general alternative. The equation standard errors reported are the square root of the average of the squared residuals, corrected for degrees of freedom.

We also consider several kinds of generalizations of these models. The first concerns the demeaning procedure, i.e. setting up our models in terms of regional deviations from the means

\footnotetext{
${ }^{10}$ Also, in the earnings equations, we test the effect of the change in the contemporaneous relative unemployment rates, and in the unemployment equation we test the effect of the change in contemporaneous relative earnings (instrumenting appropriately). 
for Great Britain. There are plausible arguments to suggest that regional interactions are different for contiguous than for more widely spatially separated regions. These arise, for example, in the context of migration and commuting flows (see Jackman and Savouri, 1992; Cameron and Muellbauer, 1998). In the latter paper, contiguity effects are modelled in detail, using employment weighted average values of the variables of regions contiguous to region $i$.

The long-run solution for relative log earnings and the unemployment rate, equation (2), can be rewritten as ${ }^{11}$

$$
y_{i}=Y_{i}-Y_{\mathrm{GB}}=\theta_{i}+\sum_{j=1}^{k} \beta_{j}\left(X_{j i}-X_{j \mathrm{~GB}}\right)
$$

where $x_{j i}=X_{j i}-X_{j \mathrm{~GB}}$. Formulating an analogous equation for deviations from contiguous regions gives

$$
y_{c i}=Y_{i}-Y_{c i}=\theta_{i}^{*}+\sum_{j=1}^{k} \beta_{j}^{*}\left(X_{j i}-X_{j c i}\right)
$$

where $c i$ refers to the average for the regions contiguous to region $i$. Weighting the two equations by $(1-\lambda)$ and $\lambda$ respectively gives a formulation nesting both. We generalize equation (1) by replacing the equilibrium correction term based on a one-year lag of (3) by one based on a one-year lag of this nested formulation ${ }^{12}$. However, for all three dependent variables, the estimated values of $\lambda$ and the $\lambda \beta_{j}^{*}$ terms are jointly insignificant, suggesting that this formulation of contiguity effects offers no significant improvement for either the earnings or the unemployment equations. However, note that our formulation imposes the same short-run dynamics, irrespective of contiguity.

A second generalization is to relax the restriction that the speeds of adjustment and the shortrun dynamics are identical in each region using the pooled mean group (PMG) estimator as recommended by Pesaran, Shin and Smith (1999). This generalizes equation (1) by allowing $\alpha, \gamma_{s}$, and $\gamma_{j s}$ but not $\beta_{j s}$, albeit in the parsimonious forms of the models, to differ across regions. The PMG $\alpha, \gamma_{s}$, and $\gamma_{j s}$ coefficients are calculated from the simple average of the region coefficients and the estimated standard errors reported are the standard deviations of the coefficients across regions. We also consider a third generalization where all parameters are region-specific.

We model the deviation of regional log earnings from the log of average earnings for Great Britain rather than the deviation between regional log earnings from their predicted value when the region's industrial structure is applied to national average earnings by industry as in Blackaby and Manning (1992). There are two reasons for this. One is that we want to derive a one-year-ahead forecasting model for regional differentials. The other is that we prefer a more 'structural' model in which the interactions of macroeconomic variables with regional economic structures are made explicit.

We exclude long-term unemployment, being unable to find a significant effect in any of the earnings equations. However, we investigate whether the unemployment effects enter in log or levels form. The evidence is consistent with a long-run log unemployment effect, as in Sargan (1964), Layard and Nickell (1986) and in most of the country studies in Layard, Nickell and Jackman (1991). However, short-term unemployment effects fit better in terms of changes in levels rather than changes in logs.

\footnotetext{
${ }^{11}$ These are defined as $\ln e_{i}-\ln e_{\mathrm{GB}}$, where $e_{i}$ and $e_{\mathrm{GB}}$ are the average earnings of the group in region $i$ and Great Britain respectively.

${ }^{12}$ Where the $\theta_{i}^{*}$ are not identifiable. 


\section{EMPIRICAL RESULTS}

\subsection{Two Models of Relative Regional Earnings}

\section{Full-time Men's Relative Earnings}

The men's earnings version of equation (1) was reduced to the more parsimonious specification reported in Table I, column 1. There is a significant equilibrium-correction term with $\alpha$ around 0.45 which implies that earnings return quickly to their equilibrium levels. There are two points to note here. First, the presence of this term means that the equation can be interpreted as a conditional convergence regression, with the implication that relative steady-state income is determined by the other variables in the model. Second, this is evidence against Blanchflower and Oswald's contention that autoregression is unimportant in wage equations (1994, p. 284).

The lagged log level of the deviation of regional unemployment from the national level has a significant and negative effect with a long-run coefficient around -0.034 , one third of the -0.1 figure claimed by Blanchflower and Oswald as a robust order of magnitude of the slope of the wage curve. Contemporaneous changes in unemployment were instrumented using the forecast changes from the model described in the next section, but were found to be insignificant. One possible reason for this is that the NES earnings data are observed in April while the unemployment rates are annual averages. However, there is a strong negative effect from the change in the previous year's relative unemployment rate.

Turning to the housing market effects, lagged relative house prices have a positive and highly significant effect on relative earnings, and this effect has become stronger as the proportion of owner-occupation in the UK has risen. Note that the proportion of owner-occupation in the UK produces a more significant coefficient here than if the proportion of owner-occupation in the region is used or than if relative log house prices are unweighted. At a UK owner-occupation proportion of 0.68 , the long-run effect of relative log house prices on men's relative full-time earnings is 0.075 . Relative mortgage costs in the previous year have a positive effect on relative earnings. But a rise in mortgage interest rates 2 years earlier has a temporary negative effect on relative earnings in regions with high ratios of mortgage debt to earnings. This appears to reflect the long-term recessionary implications of higher interest rates on regions with high debt to income ratios. Last year's expectation of a rise in this year's bank base rate, interacted with the relative proportion of employment in banking and financial services, has a negative effect on relative earnings. There is no evidence of a spill-over effect from women's relative regional earnings.

Lastly, we have the composition effects. Since this is a model of men's earnings, it is interesting that regions with high proportions of part-time women have lower relative men's earnings, suggesting an element of substitution between these groups of workers, or that a high proportion of part-time women signals weak labour demand. We also find that men's earnings in regions with more production workers suffer more when competitiveness falls (that is, the log real exchange rate rises) and that men's earnings in regions with more banking and financial sector workers do better when there is financial liberalization.

Column 2 of Table I presents the short-sample estimate of the model, from 1972 to 1987. This omits the peak of the 1980s house price boom and the 1990s housing market crisis, a severe test of parameter stability. There are no significant differences in estimated coefficients, though the point estimate of the lagged weighted change in mortgage interest rates falls, and the restriction of no structural break cannot be rejected at the 5\% level, $F_{80,138}=1.10[P=0.31]$. 
Table I. Full-time men's relative earnings model

\begin{tabular}{|c|c|c|c|c|c|}
\hline Parameter & & $\begin{array}{l}\text { Model } 1 \\
\text { Baseline }\end{array}$ & $\begin{array}{l}\text { Model } 2 \\
\text { short sample }\end{array}$ & $\begin{array}{c}\text { Model } 3 \\
\text { Actual } \Delta U(i t)\end{array}$ & $\begin{array}{l}\text { Model } 4 \\
\text { PMG }\end{array}$ \\
\hline $\begin{array}{l}\text { Rel. log men's full-time earnings } \\
(i t-1)\end{array}$ & $\alpha$ & $0.446(0.033)$ & $0.487(0.055)$ & $0.449(0.032)$ & $0.515(0.136)$ \\
\hline Rel. log unemployment (it-1) & $\beta$ & $-0.034(0.009)$ & $-0.042(0.011)$ & $-0.050(0.009)$ & $-0.032(0.009)$ \\
\hline $\begin{array}{l}\Delta \text { Rel. unemployment/100 (it) (not } \\
\text { instrumented) }\end{array}$ & $\gamma$ & & & $-0.742(0.121)$ & \\
\hline$\Delta$ Rel. unemployment/100 (it-1) & $\gamma$ & $-0.397(0.123)$ & $-0.345(0.180)$ & $-0.703(0.116)$ & $-0.113(0.977)$ \\
\hline $\begin{array}{l}\text { Rel. log house prices }(i t-1)^{*} \mathrm{UK} \\
\text { prop. owner-occupied }(t-1)\end{array}$ & $\beta$ & $0.114(0.015)$ & $0.120(0.033)$ & $0.136(0.157)$ & $0.119(0.017)$ \\
\hline $\begin{array}{l}\text { Weighted av. Building Society } \\
\text { mortgage rate } / 100(\text { it }-1)\end{array}$ & $\beta$ & $0.283(0.106)$ & $0.252(0.206)$ & $0.461(0.108)$ & $0.252(0.133)$ \\
\hline $\begin{array}{l}\text { Weighted } \Delta \text { av. Building Society } \\
\text { mortgage rate } / 100 \text { (it-2) }\end{array}$ & $\gamma$ & $-0.771(0.104)$ & $-0.337(0.224)$ & $-0.801(0.091)$ & $-0.967(1.282)$ \\
\hline $\begin{array}{l}\text { Rel. prop. Part-time women in total } \\
\text { women }(i t-1)\end{array}$ & $\beta$ & $-0.700(0.120)$ & $-0.656(0.156)$ & $-0.691(0.123)$ & $-0.699(0.130)$ \\
\hline Rel. prop. Production workers (it-1) & $\beta$ & $0.036(0.083)$ & $0.013(0.135)$ & $0.129(0.083)$ & $0.111(0.102)$ \\
\hline Rel. prop. Bank workers $(i t-1)$ & $\beta$ & $0.542(0.184)$ & $0.522(0.314)$ & $0.454(0.187)$ & $0.489(0.231)$ \\
\hline $\begin{array}{l}\text { Rel. prop. Production } \\
\text { workers }(i t-1)^{*} \log \text { real ex } \\
\text { rate }(t-1)\end{array}$ & $\beta$ & $-0.518(0.210)$ & $-0.526(0.230)$ & $-0.053(0.219)$ & $-0.484(0.223)$ \\
\hline $\begin{array}{l}\text { Rel. prop. Bank } \\
\quad \text { workers }(i t-1)^{*} \text { financial } \\
\text { liberalization }(t-1) \\
\text { Rel. prop. Bank workers }(M A, t-1)^{*}\end{array}$ & $\beta$ & $1.776(0.377)$ & $1.769(0.475)$ & $2.175(0.393)$ & $1.695(0.437)$ \\
\hline $\begin{array}{l}\text { Rel. prop. Bank workers }(M A, t-1)^{*} \\
\quad \text { fitted } \Delta \text { base rate/100 }(\mathrm{UK}, t)\end{array}$ & $\gamma$ & $-2.098(0.816)$ & $-2.598(1.194)$ & $-2.492(0.796)$ & $-3.030(2.730)$ \\
\hline $\begin{array}{l}\text { North } \\
\text { North-West }\end{array}$ & $\begin{array}{l}\theta \\
\theta\end{array}$ & $\begin{array}{r}0.007(0.009) \\
-0.004(0.005)\end{array}$ & $\begin{array}{r}0.011(0.017) \\
-0.001(0.001)\end{array}$ & $\begin{array}{r}0.015(0.008) \\
-0.005(0.005)\end{array}$ & $\begin{array}{r}0.002(0.011) \\
-0.007(0.006)\end{array}$ \\
\hline Yorkshire \& Humberside & $\theta$ & $0.004(0.008)$ & $0.007(0.019)$ & $0.006(0.008)$ & $0.001(0.011)$ \\
\hline West Midlands & $\theta$ & $-0.038(0.010)$ & $-0.036(0.017)$ & $-0.045(0.009)$ & $-0.049(0.012)$ \\
\hline East Midlands & $\theta$ & $-0.042(0.010)$ & $-0.044(0.019)$ & $-0.052(0.010)$ & $-0.049(0.011)$ \\
\hline East Anglia & $\theta$ & $-0.039(0.006)$ & $-0.043(0.008)$ & $-0.043(0.006)$ & $-0.037(0.006)$ \\
\hline South East & $\theta$ & $0.043(0.010)$ & $0.037(0.021)$ & $0.039(0.010)$ & $0.053(0.014)$ \\
\hline South West & $\theta$ & $-0.042(0.007)$ & $-0.046(0.009)$ & $-0.044(0.007)$ & $-0.038(0.008)$ \\
\hline Wales & $\theta$ & $-0.031(0.007)$ & $-0.025(0.011)$ & $-0.026(0.007)$ & $-0.031(0.009)$ \\
\hline Scotland & $\theta$ & $-0.015(0.007)$ & $-0.010(0.008)$ & $-0.006(0.006)$ & $-0.017(0.008)$ \\
\hline Number of observations & & 240 & 160 & 240 & 240 \\
\hline Sample period & & $1972-1995$ & $1972-1987$ & $1972-1995$ & $1972-1995$ \\
\hline Equation standard error & & 0.00833 & 0.00843 & 0.00813 & 0.00820 \\
\hline AR test $(F)$ & & $1.26[0.29]$ & $3.52[0.03]$ & $0.62[0.54]$ & $1.67[0.19]$ \\
\hline HS Test $(F)$ & & $0.15[0.70]$ & $1.07[0.30]$ & $0.01[0.91]$ & $0.70[0.40]$ \\
\hline $\mathrm{L} \overline{\mathrm{M}}$ & & 12.13 & 8.61 & 11.60 & 12.83 \\
\hline
\end{tabular}

Notes: Heteroscedasticity-Consistent Standard Errors in parentheses. Dependent variable is the change in log relative full-time men's earnings. Estimation is by SUR in TSP (Hall et al. 1995). Equation standard error is the square root of the average of the squared residuals, corrected for degrees of freedom. Following the notation in equation (1), $\alpha$ is the speed of adjustment; $\beta$ are long-run coefficients; $\gamma$ are dynamic terms; $\theta$ are long-run fixed effects. Pooled Mean Group (PMG) $\alpha$ and $\gamma$ coefficients are calculated from the simple average of the region coefficients and their estimated standard error is the standard deviation of the coefficients across regions.

AR $\quad F$-test for first- and second- order serial correlation, (Breusch and Pagan 1980).

HS $F$-test for heteroscedasticity (White, 1980).

$\mathrm{L} \overline{\mathrm{M}}$ Test for non-stationary residuals based on Im, Pesaran and Shin (1997), 5\% critical value (approx.): 3.96.

Having found no significant effect for the forecast from the unemployment equation, we can compare these results with those using the actual unemployment data (see column 3 of Table I). The 
Table II. Full-time women's relative earnings model

\begin{tabular}{|c|c|c|c|c|c|}
\hline Parameter & & $\begin{array}{l}\text { Model } 1 \\
\text { Baseline }\end{array}$ & $\begin{array}{c}\text { Model } 2 \\
\text { short sample }\end{array}$ & $\begin{array}{l}\text { Model } 3 \\
\text { PMG }\end{array}$ & $\begin{array}{l}\text { Model } 4 \\
\text { Comparison }\end{array}$ \\
\hline $\begin{array}{l}\text { Rel. log women's full-time } \\
\text { earnings (it-1) }\end{array}$ & $\alpha$ & $0.456(0.050)$ & $0.547(0.070)$ & $0.567(0.115)$ & $0.408(0.042)$ \\
\hline $\begin{array}{l}\Delta \text { Rel. log women's full-time } \\
\text { earnings }(i t-1)\end{array}$ & $\gamma$ & $-0.231(0.050)$ & $-0.187(0.061)$ & $-0.192(0.132)$ & \\
\hline $\begin{array}{l}\Delta \text { Rel. unemployment/100 (it) } \\
\quad \text { (instrumented) } \\
\text { Rel. log house prices }(i t-1)^{*} \mathrm{UK}\end{array}$ & $\gamma$ & $-0.559(0.152)$ & $-0.505(0.239)$ & $-0.566(0.923)$ & $-0.241(0.120)$ \\
\hline prop. owner-occupied $(t-1)$ & $\beta$ & $0.179(0.023)$ & $0.170(0.036)$ & $0.159(0.023)$ & $0.108(0.020)$ \\
\hline Rel. prop. production workers (it-1) & $\beta$ & $0.025(0.089)$ & $-0.021(0.111)$ & $0.098(0.105)$ & $0.032(0.099)$ \\
\hline Rel. prop. banking workers $(i t-1)$ & $\beta$ & $-0.458(0.243)$ & $-0.095(0.291)$ & $-0.644(0.283)$ & $-0.133(0.203)$ \\
\hline $\begin{array}{l}\text { Rel. prop. production } \\
\text { workers }(i t-1)^{*} \log \text { real ex } \\
\text { rate }(t-2)\end{array}$ & $\beta$ & $-0.790(0.166)$ & $-0.700(0.161)$ & $-0.678(0.161)$ & \\
\hline $\begin{array}{l}\text { Rel. prop. production } \\
\text { workers }(i t-1)^{*} \log \text { real ex } \\
\text { rate }(t-1)\end{array}$ & & & & & $-0.622(0.171)$ \\
\hline $\begin{array}{l}\text { Rel. prop. bank } \\
\text { workers }(i t-1)^{*} \text { financial } \\
\text { liberalization }(t-1)\end{array}$ & $\beta$ & $1.980(0.304)$ & $1.571(0.306)$ & $2.308(0.391)$ & $2.616(0.326)$ \\
\hline North & $\theta$ & $-0.046(0.010)$ & $-0.029(0.014)$ & $-0.039(0.010)$ & $-0.046(0.010)$ \\
\hline North-West & $\theta$ & $-0.033(0.006)$ & $-0.028(0.008)$ & $-0.021(0.007)$ & $-0.036(0.006)$ \\
\hline Yorkshire \& Humberside & $\theta$ & $-0.057(0.010)$ & $-0.047(0.014)$ & $-0.038(0.009)$ & $-0.058(0.009)$ \\
\hline West Midlands & $\theta$ & $-0.066(0.012)$ & $-0.049(0.015)$ & $-0.039(0.011)$ & $-0.062(0.012)$ \\
\hline East Midlands & $\theta$ & $-0.080(0.014)$ & $-0.065(0.017)$ & $-0.054(0.022)$ & $-0.073(0.014)$ \\
\hline East Anglia & $\theta$ & $-0.061(0.005)$ & $-0.052(0.006)$ & $-0.037(0.010)$ & $-0.058(0.006)$ \\
\hline South East & $\theta$ & $0.108(0.013)$ & $0.088(0.017)$ & $0.057(0.010)$ & $0.096(0.013)$ \\
\hline South West & $\theta$ & $-0.056(0.005)$ & $-0.054(0.005)$ & $-0.024(0.006)$ & $-0.054(0.005)$ \\
\hline Wales & $\theta$ & $-0.047(0.010)$ & $-0.034(0.011)$ & $-0.044(0.010)$ & $-0.041(0.010)$ \\
\hline Scotland & $\theta$ & $-0.040(0.005)$ & $-0.039(0.005)$ & $-0.028(0.010)$ & $-0.040(0.005)$ \\
\hline Number of observations & & 240 & 160 & 240 & 240 \\
\hline Sample perio & & $1972-1995$ & $1972-1987$ & $1972-1995$ & $1972-1995$ \\
\hline Equation standard error & & 0.00951 & 0.00943 & 0.00948 & 0.009693 \\
\hline AR test $(F)$ & & $1.56[0.21]$ & $2.88[0.06]$ & $2.80 \quad[0.06]$ & $10.05 \quad[0.00]$ \\
\hline HS test $(F)$ & & $2.30[0.13]$ & $1.08[0.30]$ & $4.90[0.03]$ & $11.67 \quad[0.00]$ \\
\hline $\mathrm{L} \overline{\mathrm{M}}$ & & 11.47 & 7.37 & 11.46 & 14.31 \\
\hline
\end{tabular}

Notes: Heteroscedasticity-consistent standard errors in parentheses. Dependent variable is the change in log relative full-time women's earnings. See also Notes to Table I.

coefficient on the contemporaneous change in the unemployment rate is now significantly negative $(t=6.1)$, evidence consistent with a notable endogeneity bias. Also the estimated long-run slope of the wage curve is -0.050 as opposed to -0.034 when current unemployment is instrumented or omitted. Part of the estimated negative effect of current unemployment on current earnings is probably due to common demand shocks which raise unemployment and depress wages. This suggests that Blanchflower and Oswald's claims of a slope of -0.1 for the wage curve may be exaggerated because of endogeneity bias, a possibility noted by Card (1995).

We also test the Table I, column 1, baseline model against the pooled mean groups estimator of Pesaran et al. (1999), where speeds of adjustment and short-run dynamics are allowed to differ across regions, as shown in column 4. A test of the baseline model against this alternative, given the error covariance matrix of the baseline model, cannot reject the baseline model, $F_{35,183}=1.35$ 
$[P=0.11]$. A test of the baseline model against the even more general alternative that all parameters are permitted to vary by region also cannot reject the baseline model, $F_{108,110}=1.03$ $[P=0.44]$.

One of the most interesting results from Table I is that the long-run coefficient on relative house prices, 0.075 at a UK owner-occupation proportion of 0.68 , though highly significant, is only around one half Blackaby and Manning's estimate of 0.15 . Of the various differences in specification between their model and Table I, an important one is their omission of the interaction between financial liberalization and the proportion of employment in the banking sector. Excluding this variable pushes the long-run coefficient on relative house prices up to 0.11 . If we further exclude the interaction of the real exchange rate with the proportion of employment in the production sector and exclude the proportion of employment accounted for by part-time women, the long-run house price coefficient rises to 0.19. This suggests that, in Blackaby and Manning's model, house prices may, in part, be proxying more fundamental structural changes in the economy which influence both house prices and earnings.

For non-manual men's full-time earnings, we expect to find stronger house price effects than for men's full-time earnings, as discussed in Section 2. These expectations are confirmed by the empirical findings. The long-run coefficient on relative house prices at a UK owner-occupation proportion of 0.68 is 0.12 for non-manual men compared with 0.075 for all full-time men. The long-run log unemployment effect is zero: there is no 'wage curve' for non-manual men. Again, this is not a big surprise since manual workers dominate the aggregate unemployment rate. For manual men, however, we estimate the long-run slope of the wage curve to be -0.07 , now much closer to the Blanchflower and Oswald figure of -0.1 and close to the estimate of Jackman, Layard, and Savouri (1992) of -0.067. There is no significant long-run house price effect.

Full-time Women's Relative Earnings

For full-time women's earnings, we formulated a model according to equation (1) and again followed a general to simple model selection procedure (see Table II). In contrast to full-time men's earnings, we could find no influence from mortgage costs (though the point estimate is positive, $t=1.3$ ), the proportion of women's employment that is part-time, and no wage curve. However, the contemporaneous change in the unemployment rate (appropriately instrumented) has a very significant negative effect, presumably capturing demand shocks. The speed of adjustment is 0.46 and there is also a negative response to the previous year's change in relative log earnings for full-time women.

There is no spill-over effect from men's relative regional earnings. As in the earnings equation for men, the proportion of employment in the production sector (interacted with the real exchange rate, but at a lag of two years) has a negative effect on relative women's earnings. The interaction of financial liberalization with the proportion of employment in banking has a similarly large positive effect on women's as on men's earnings. To the extent that the new technology increases job migration, we might expect it to decrease the extent to which higher house prices translate into higher earnings and to reduce the impact of the fixed effects. As with the full-time men's earnings equation, we find no significant effect of this kind for women. Finally, although the relative house price effect is represented by the lagged two year moving average, i.e. on average, half a year further back than for men, the long-run coefficient is around 0.10 at an owner-occupation proportion of 0.68 , even larger than for full-time men.

Table II, column 2, also shows results for the 1972-87 subsample with a somewhat weaker effect from the change in the unemployment rate but otherwise very similar parameters. An $F$-test for parameter stability cannot be rejected, $F_{80,120}=1.11[P=0.31]$. Table II, column 3 , shows 
results for the pooled mean groups version of the model allowing speeds of adjustment and dynamics to differ across regions. The baseline model (column 1) cannot be rejected against this alternative, $F_{54,146}=0.82[P=0.54]$, or against the alternative that all coefficients differ across regions, $F_{90,110}=1.25[P=0.13]$. To demonstrate the robustness of our results, Table II, column 4 , shows the specification that results from testing-down from a model equivalent to the mens' earnings baseline model from Table I, column 1. There is no wage-curve, and the weighted real exchange rate and house price effects remain highly significant.

\subsection{A Model of Relative Regional Unemployment}

In the long run, we expect the relative unemployment rate to increase with the relative earnings of full-time men and women, via the effect on regional labour demand, other things being equal. Section 2 argues that the effect of relative house prices is, in principle, ambiguous, but on balance, more likely to raise relative unemployment in the long-run.

Relative unemployment rates can also be expected to be affected in the long-run by industrial structure and its interaction with macroeconomic variables such as international competitiveness (measured by the real exchange rate), financial liberalization, UK real house prices, and changes in technology. In the long run, the share of employment in production industries has declined, while that in services, particularly financial services, has risen across OECD countries. However, since the late 1980s, the fall in the price of computing power, the availability of new software and, probably, lower telephone charges, has led to a rise in on-line financial service provision and in 'call centres', where large numbers of employees are engaged in selling and providing information or responding to customer requests. It has therefore become less important for these activities to be located close to the customers. These changes in technology suggest greater job mobility: a bigger rôle for relative labour and housing cost variables in the location of businesses and a smaller rôle for the locational advantages represented by the fixed effects, the $\theta_{i}$, in our model. We capture these effects in a single parameter, which represents the proportionate fall beginning in 1989 of the $\theta_{i}$, and the proportionate rise in the coefficients on relative men's and women's earnings and relative house prices.

After a series of simplifications, we arrived at a parsimonious model. To check parameter stability we estimated the model for 1972-87 using the same covariance matrix as for the full sample. An $F$-test of no parameter shift between the short and long samples gave $F_{80,137}=1.42$ $[P=0.036]$, which is significant at the 5\% level, casting doubt on the model's validity. As noted in Section 3, we then considered several kinds of generalizations of these models. The first concerned the de-meaning procedure, i.e. testing for contiguity effects, but these were found to be insignificant. The second generalization is to relax the restriction that the speeds of adjustment and the short-run dynamics are identical in each region (see Table III, column 3. We test the baseline models against this generalization holding constant the covariance matrix of errors in the baseline model, $F_{34,181}=1.46[P=0.057]$. This $p$-value suggests that there is something to be learnt from the more general specification. The most striking feature of the results is the significantly higher speed of adjustment for Wales and Scotland than for the other regions.

This suggested a slight generalization of the baseline model where $\alpha$ is allowed to differ for Wales and Scotland but is the same for the other eight regions, but otherwise all the other shortrun dynamics are restricted to be the same across regions. The results for this extended base-line model are shown in column 1 Table III. 
Table III. Relative unemployment rate model

\begin{tabular}{|c|c|c|c|c|c|c|c|}
\hline \multirow{2}{*}{$\begin{array}{l}\text { Parameter } \\
\text { Rel. unemployment rate (it-1) }\end{array}$} & \multirow[b]{2}{*}{$\alpha$} & \multicolumn{2}{|c|}{$\begin{array}{l}\text { Model } 1 \\
\text { Baseline }\end{array}$} & \multicolumn{2}{|c|}{$\begin{array}{l}\text { Model } 2 \\
\text { short sample }\end{array}$} & \multicolumn{2}{|c|}{$\begin{array}{l}\text { Model } 3 \\
\text { PMG }\end{array}$} \\
\hline & & 0.201 & $(0.023)$ & 0.189 & $(0.037)$ & 0.203 & $(0.039)$ \\
\hline $\begin{array}{l}\text { Rel. unemployment rate (Wales, } \\
t-1 \text { ) }\end{array}$ & $\alpha$ & 0.536 & $(0.077)$ & 0.379 & $(0.091)$ & 0.412 & $(0.093)$ \\
\hline $\begin{array}{l}\text { Rel. unemployment rate (Scotland, } \\
t-1 \text { ) }\end{array}$ & $\alpha$ & 0.377 & $(0.062)$ & 0.382 & $(0.123)$ & 0.376 & $(0.069)$ \\
\hline $\begin{array}{l}\text { Rel. log women's full-time } \\
\text { earnings (it-1) } \\
\text { Rel. log men's full-time earnings }\end{array}$ & $\beta$ & 10.90 & $(2.90)$ & 17.52 & $(6.34)$ & 9.73 & $(3.90)$ \\
\hline$(i t-2)$ & $\beta$ & 9.75 & (2.67) & 9.63 & (4.88) & 14.12 & $(4.33)$ \\
\hline$\Delta$ Rel. unemployment (it-1) & $\gamma$ & 0.351 & $(0.043)$ & 0.318 & $(0.063)$ & 0.285 & $(0.132)$ \\
\hline Rel. log house prices (it-3) & $\beta$ & 1.62 & $(0.62)$ & 4.25 & $(1.56)$ & 1.98 & $(0.86)$ \\
\hline $\begin{array}{l}\text { Weighted } \Delta 2 \text { av. Building Society } \\
\text { mortgage rate (it-2) }\end{array}$ & $\gamma$ & 0.209 & $(0.023)$ & 0.119 & $(0.047)$ & 0.153 & $(0.167)$ \\
\hline $\begin{array}{l}\text { Rel. prop. part-time women in total } \\
\text { women (it-1) } \\
\text { Rel. prop. production }\end{array}$ & $\beta$ & 23.66 & $(3.23)$ & 14.63 & $(5.30)$ & 20.24 & $(4.64)$ \\
\hline $\begin{array}{l}\text { Rel. prop. production } \\
\text { workers }(M A, t-1) \\
\text { Rel. prop. banking }\end{array}$ & $\beta$ & -7.49 & $(5.96)$ & -8.60 & $(10.03)$ & 5.81 & $(9.56)$ \\
\hline $\begin{array}{l}\text { workers }(M A, t-1) \\
\text { Rel. prop. production workers }\end{array}$ & $\beta$ & -35.97 & $(9.49)$ & -69.69 & (21.30) & -52.79 & $(15.54)$ \\
\hline $\begin{array}{l}(M A, t-1)^{*} \log \\
\text { real ex rate }(t-1)\end{array}$ & $\beta$ & 71.31 & $(10.97)$ & 69.88 & $(15.96)$ & 88.55 & $(17.47)$ \\
\hline $\begin{array}{l}\text { Rel. prop. bank workers }(i t-1)^{*} \log \\
\text { real house prices }(\mathrm{UK}, t-2)\end{array}$ & $\beta$ & -33.35 & (11.21) & -38.32 & $(18.34)$ & -28.48 & (15.89) \\
\hline $\begin{array}{l}\text { Rel. prop. banking } \\
\text { workers }(M A, t-1)^{*} \text { fitted } \Delta \text { base } \\
\text { rate }(\mathrm{UK}, t)\end{array}$ & $\gamma$ & 0.692 & $(0.169)$ & 0.788 & $(0.229)$ & 0.684 & (1.159) \\
\hline $\begin{array}{l}\text { Trend } 1989^{*} f \text { (fixed effects, } \\
\text { earnings, house prices) }\end{array}$ & & 0.094 & $(0.014)$ & & & 0.091 & $(0.022)$ \\
\hline $\begin{array}{l}\text { North } \\
\text { North-West }\end{array}$ & $\begin{array}{l}\theta \\
\theta\end{array}$ & $\begin{array}{l}0.042 \\
0.031\end{array}$ & $\begin{array}{l}(0.005) \\
(0.004)\end{array}$ & $\begin{array}{l}0.044 \\
0.037\end{array}$ & $\begin{array}{l}(0.009) \\
(0.006)\end{array}$ & $\begin{array}{l}0.033 \\
0.025\end{array}$ & $\begin{array}{l}(0.007) \\
(0.005)\end{array}$ \\
\hline Yorkshire \& Humberside & $\theta$ & 0.014 & $(0.005)$ & 0.023 & $(0.009)$ & 0.006 & $(0.007)$ \\
\hline West Midlands & $\theta$ & 0.024 & $(0.007)$ & 0.024 & $(0.012)$ & 0.010 & $(0.010)$ \\
\hline East Midlands & $\theta$ & 0.009 & $(0.007)$ & 0.012 & $(0.011)$ & -0.006 & $(0.010)$ \\
\hline East Anglia & $\theta$ & -0.019 & $(0.004)$ & -0.015 & $(0.006)$ & -0.017 & $(0.006)$ \\
\hline South East & $\theta$ & -0.034 & $(0.006)$ & -0.036 & $(0.010)$ & -0.020 & $(0.009)$ \\
\hline South West & $\theta$ & -0.011 & $(0.004)$ & -0.008 & $(0.006)$ & -0.003 & $(0.006)$ \\
\hline Wales & $\theta$ & 0.027 & $(0.003)$ & 0.026 & $(0.006)$ & 0.021 & $(0.005)$ \\
\hline Scotland & $\theta$ & 0.033 & $(0.003)$ & 0.030 & $(0.004)$ & 0.030 & $(0.004)$ \\
\hline Number of observations & & 240 & & 160 & & 240 & \\
\hline Sample period & & $1972-$ & -1995 & $1972-$ & -1987 & $1972-$ & 1995 \\
\hline Equation standard error & & 0.0025 & 5040 & 0.0023 & 3825 & 0.0024 & 1607 \\
\hline AR test $(F)$ & & 2.70 & {$[0.07]$} & 3.75 & {$[0.03]$} & 1.67 & {$[0.19]$} \\
\hline HS test $(F)$ & & 0.11 & {$[0.75]$} & 0.71 & {$[0.40]$} & 0.01 & {$[1.00]$} \\
\hline $\mathrm{L} \overline{\mathrm{M}}$ & & 10.13 & & 6.01 & & 10.59 & \\
\hline
\end{tabular}

Notes: Heteroscedasticity-consistent standard errors in parentheses. Dependent variable is the change in relative unemployment rate/100. See also Notes to Table I.

The new base-line model in column 1 shows a speed of adjustment, $\hat{\alpha}=0.20$, but 0.54 in Wales and 0.38 in Scotland. There is significant persistence in relative unemployment changes, $\hat{\gamma}_{1}=0.54$. Of the $x_{j}$ variables listed above, only the relative proportion of manual workers and the interaction of the relative size of the banking and financial services sector with the financial 
liberalization proxy proved insignificant. To interpret some of the results, a rise of $1 \%$ in relative earnings of full-time men and women eventually raises the relative unemployment rate by 0.05 percentage points, other things being equal. A rise of $10 \%$ in relative house prices eventually raises the relative unemployment rate by 0.16 percentage points, though the lags are long. A $10 \%$ rise in the real exchange rate eventually raises the relative unemployment rate in a region such as the West Midlands, which in 1980 had a percentage of employment in the production sector $9.6 \%$ higher than in Great Britain, by 0.68 percentage points.

As mentioned earlier, the formulation in column 1 has a trend beginning in 1989 which results in a proportional shift in the fixed effects and the relative earnings and housing cost effects. The parameter estimate suggests a 9.4\% per annum decline in the fixed effects beginning in 1989 and a corresponding rise in the relative earnings and housing cost effects (obviously an ogive formulation would be more appropriate in a longer dataset). The speeds of adjustment are a little higher than in the model shown in column 1 but, with some exceptions, the other parameter estimates are very similar. One exception is the coefficient on the proportion of employment in banking and insurance which is around $45 \%$ of the column 1 estimate and is now not subject to a regime shift. The coefficients for relative house price and relative earnings of women fall compared with column 1.

There are two significant interest rate effects. The first weights the two-year rise in the mortgage interest rate, lagged two years, by last year's difference from Great Britain in the mortgage debt to earnings ratio in each region. This suggests there are substantial lags before a rise in mortgage interest rates feeds, via cash flows and housing collateral values, into lower spending and higher unemployment. The other interest rate effect weights the expected value of the current change in bank base rate by the relative proportion of employment in banking and financial services. This suggests that hiring decisions in this sector respond quickly to current circumstances or have a forward-looking element. The weighted interest change lagged one year is not significant using either set of weights, though the point estimate is also positive.

Parameter stability tests for 1972-87 compared with $1972-95$ give $F_{80,135}=1.28[P=0.10]$, suggesting parameter stability can now be accepted at the $5 \%$ level. The estimates for the column 1 variant for 1972-87 are shown in column 2 . Taking the column 1 specification as the baseline, we then relax the restrictions across regions on $\alpha_{1}, \gamma_{s}, \gamma_{j s}$ but not $\beta_{j s}$, (see column 3). These results suggest that the column 1 specification gives estimates which well represent the averages of the more general pooled mean groups estimator. An $F$-test of the column 1 specification, fixing its covariance matrix of errors, against the more general alternative, gives $F_{34,181}=1.08[P=0.36]$, implying that the column 1 specification can be accepted. Finally, we carried out the analogous test of the column 1 model against the model where all parameters differ across regions. This gives $F_{115,100}=1.03[P=0.43]$ implying the parsimonious model can be accepted against the most general alternative.

Why the speed of adjustment should be higher for Wales and Scotland remains a puzzle. One hypothesis is that regional policy has been more active in these regions and has reacted against rises in unemployment rates in these regions, bringing a speedier convergence to long-run levels than for the remaining regions.

\section{CONCLUSIONS}

In this paper we have analysed panel data for 1972-95 on relative regional earnings for full-time men and women and for the relative unemployment rates for the ten standard regions of Great 
Britain. The earnings data come from the New Earnings Survey and refer to gross weekly earnings of workers not affected by absence.

Regarding the earnings-unemployment relationship, a negative long-run effect for log unemployment on log earnings as in Sargan (1964) and Blanchflower and Oswald (1994) was confirmed for full-time men. A further split between manual and non-manual men showed there to be no effect for the latter and a coefficient of around -0.07 for manual men. For full-time women, there is also no evidence of a negative long-run effect though rises in relative regional unemployment rates are associated with declines in relative regional full-time earnings of women. However, note that we have used the unemployment rate for all workers in these models. This will tend to under-estimate the size of the wage curve when the elasticity of group unemployment with respect to aggregate unemployment is less than one. Formally, if $a$ is the wage curve for group unemployment, and $e$ is the elasticity of group unemployment with respect to aggregate unemployment, then the wage curve using aggregate unemployment will be $a e$, conditional on other variables. Thus, if the wage curve is formulated in terms of the unemployment rate for all workers, it is not a universal phenomenon in the British labour market. Moreover, our evidence is that any failure to instrument the current unemployment rate results in an over-estimate of the negative effect of unemployment on earnings.

The second objective of the paper was to investigate housing market effects on earnings. Our findings suggest a long-run coefficient of around 0.075 for full-time men and around 0.10 for full-time women of relative regional house prices on relative regional earnings. Though the effects are highly significant, they contrast with a coefficient of 0.15 estimated by Blackaby and Manning (1992) on data for full-time men for 1972-88.

Further disaggregation of men into non-manuals and manuals reveals a striking difference in the house price effects: 0.12 for non-manuals and no significant effect for manual men. These appear to reflect the known differences in migration rates and in rates of owner-occupation between the two groups of workers. These house price effects on wages exclude effects operating via national bargaining which tend to be eliminated in taking regional deviations. At the macroeconomic level, the effects are therefore likely to be larger.

Regarding the determination of regional differences in unemployment rates, we find a strong positive effect of lagged earnings on unemployment. Thus, regions with higher labour costs, tend, other things being equal, to suffer higher unemployment. Job migration may well be a significant aspect of this tendency.

Job migration also helps to explain the positive long-run relative house price effect on relative unemployment rates. Net job migration rates, on which we lack data, are likely to respond negatively to high relative regional land costs, which will be correlated with house prices, suggesting a positive relative house price effect on relative unemployment rates. We expect the effect of people migration to be in the opposite direction, since people migration is sensitive to relative house prices (see Cameron and Muellbauer, 1998). However, there are good reasons to think that the effect on unemployment is small. Most of regional migration is by nonmanual workers and these are more likely to be sensitive to house prices. They also have low unemployment rates and so have less impact on average unemployment rates for all workers. Indeed, if manual workers and non-manual workers are joint inputs in production, the net migration of non-manuals from a region in response to high relative house prices in that region may destroy jobs or impede job creation for manual workers in that region.

Our unemployment equation, like our earnings equations for manual men and for women shows a strong effect from the lagged real exchange rate interacted with the proportion of employment in the production sector. This makes an important contribution to understanding the "North-South 
divide' as reflected in low unemployment and higher earnings in the South East and its contiguous regions, particularly in the late 1980s and resurfacing recently. There also appear to be effects from interactions between the proportion of employment in the banking and financial services sector with current changes in interest rates and past levels of real UK house prices, which are associated with cyclical fluctuations in this sector.

There is indirect evidence that from about 1989, job migration rates have tended to increase, which we believe is the results of new and cheaper information technology reducing the need for service sector firms to be located close to their customers. We find significant evidence that this has resulted in a narrowing of long-run regional unemployment differentials and has increased responses of relative unemployment rates to regional differences in labour and housing costs. We also investigated the connection between high levels of owner-occupation (or low levels of private-tenancy) and high levels of unemployment emphasized on theoretical and empirical grounds by Oswald (1998). However, as forewarned in Section 2, we were unable to find significant effects either in our most general or our most parsimonious specification of our model of regional unemployment rates.

This paper has implications for the interpretation of the results of Blanchard and Katz (1992, 1997). One is that omitted variable bias may have contributed to their finding of a high degree of wage persistence-we also find high levels of persistence when relative house price effects and interactions of macroeconomic variables with regional characteristics are omitted. More generally, the UK evidence is that housing market fluctuations fluctuations are far from being simple functions of earnings and employment shocks (see Muellbauer and Murphy, 1994, 1997). For the USA, even though housing supplies are more elastic than in the UK, it would be surprising if these fluctuations did not also contribute to regional evolutions.

\section{DATA APPENDIX}

\section{Descriptions of Variables}

$L F T M E_{i} \quad$ Log real average weekly earnings of full-time men. Source: New Earnings Survey. $[0.105,0.032]$

$L F T F E_{i} \quad$ Log real average weekly earnings of full-time women. Source: New Earnings Survey. [0.109, 0.024]

$U_{i} \quad$ Regional unemployment rate/100(all workers, claimant count). Source: Employment Gazette, various issues. [-1.640, 0.932]

$U H_{i} \quad$ Regional unemployment rate/100(all workers, claimant count), fitted value from unemployment equation. $[-1.396,0.571]$

$P P_{i} \quad$ Share of production workers in total employment. Source: Office for National Statistics, Earnings and Employment Division. [-0.073, 0.008]

$P B_{i} \quad$ Share of banking, finance and real estate workers in total employment. Source: Office for National Statistics, Earnings and Employment Division. [0.043, 0.009]

$P F P T_{i} \quad$ Share of part-time women in total women workers. Source: Office for National Statistics, Earnings and Employment Division. [-0.019, 0.016]

$L H P_{i} \quad$ Log mix-adjusted second-hand house prices. Source: Department of Environment, Transport and the Regions. [0.178, 0.072]

POO Proportion of owner-occupiers in UK. Source: Housing and Construction Statistics, Department of Environment, Transport and the Regions. [0.596, 0.057] 
$W R R_{i} \quad$ Average UK Building Society mortgage interest rate weighted by mortage debt to income ratio in region (relative to GB). Source: Cameron and Muellbauer (1998). [3.624, 1.958]

RER The real exchange rate. Source: Economic Trends. [0.014, 0.107]

$\triangle M L R H \quad$ Fitted value for change in UK bank base rates from a simple autoregressive forecasting model with US 3 month Treasury Bill interest rate, inflation, the trade balance to GDP ratio and the change in personal income. [-0.101, 2.087]

$A F L I B \quad$ Financial liberalization proxy defined as the moving average of the proportion of first-time buyers (excluding buyers at subsidized prices of social housing by former tenants) obtaining mortgages of $90 \%$ or more. This rose from an average of 0.319 between 1972 and 1977 to 0.675 between 1985 and 1990. The variable is defined as the deviation from its mean over 1972 to 1995 . Source: special tabulations from the 5\% Survey of Building Society Mortgages, DETR. [0.001, 0.165]

Trend89 Split time trend which is zero until 1988, one in 1989, two in 1990, etc. [0.913, 1.807]

Note: means and standard deviations in brackets, for the South East only in the case of regional variables.

Table I. Dynamic panel data unit root tests

\begin{tabular}{lcr}
\hline & Levels & Differences \\
\hline LFTME & 2.51 & 11.51 \\
LFTFE & 1.58 & 14.41 \\
U & 0.68 & 5.99 \\
PP & 2.41 & 10.10 \\
PB & 2.46 & 9.92 \\
PFPT & 2.96 & 12.54 \\
LHP & 2.20 & 8.86 \\
WRR & 1.11 & 7.87 \\
\hline
\end{tabular}

Notes: 5\% Critical value (approx.): 3.96 from Im et al. (1997, table 3). Sample period is $1972-95$

\section{ACKNOWLEDGEMENTS}

This research was funded by ESRC grant number R00023 7500, 'Modelling Non-Stationarity in Economic Time Series'. We are particularly grateful for patient help and advice on data issues to Derek Bird, Jude Hillary, Tim Holt, Guy Manley, James Partington, Jane Roberts, and Dev Virdee. We would also like to thank Danny Blanchflower, Damon Clark, Gavan Conlon, Clint Cummins, David Hendry, Stephen Nickell, Andrew Oswald, Jonathan Temple and participants at the European Economic Association conference in Santiago, the 8th World Congress of the Econometric Society in Seattle, and at seminars in Oxford and York for helpful discussions. We have also benefited from access to an unpublished paper by Brian Bell and comments from the editor and an anonymous referee, but take full responsibility for any errors. 


\section{REFERENCES}

Bell B. 1997. Notes on the wage curve. Mimeo, Institute of Economics and Statistics: Oxford University.

Blackaby D, Manning A. 1992. Regional earnings and unemployment-a simultaneous approach. Oxford Bulletin of Economics and Statistics 54: 481-501.

Blanchard O, Katz L. 1992. Regional evolutions. Brookings Papers on Economic Activity, 0(1): 1-61.

Blanchard O, Katz L. 1997. What we know and do not know about the natural rate of unemployment. Journal of Economic Perspectives 11: 51-72.

Blanchflower D, Oswald A. 1994. The Wage Curve. MIT Press: Cambridge, MA.

Blanchflower D, Oswald A. 1995. An introduction to the wage curve. Journal of Economic Perspectives 9 : $153-167$.

Bover O, Muellbauer J, Murphy A. 1989. House prices, wages and the UK labour market. Oxford Bulletin of Economics and Statistics 51: 97-136.

Breusch T, Pagan A. 1980. The LM tests and its application to model specification in econometrics. Review of Economic Studies 47: 239-254.

Cameron G, Muellbauer J. 1998. The housing market and regional commuting and migration choices. Scottish Journal of Political Economy 45: 420-446.

Cameron G, Muellbauer J. 2000. Earnings biases in the UK regional accounts: some economic policy and research implications. Economic Journal 110: no. 464, F412-429.

Card D. 1995. The wage curve: a review. Journal of Economic Literature 33: 785-799.

Friedman M. 1968. The role of monetary policy. American Economic Review 58: 1-17.

Greene W. 1993. Econometric Analysis. Macmillan: New York.

Hall R. 1970. Why is the unemployment rate so high at full employment? Brookings Papers on Economic Performance 3: 369-410.

Hall B, Cummins C, Schnake R, 1995. Time Series Processor version 4.3. TSP International: Palo Alto, CA.

Harris J, Todaro M, 1970. Migration, unemployment and development: a two-sector analysis. American Economic Review 60: 126-142.

Hendry D, 1997. The econometrics of macroeconomic forecasting. Economic Journal 107: 1330-1357.

Hughes G, McCormick B. 1987. Housing markets, unemployment and labour market flexibility in the UK. European Economic Review 31: 615-641.

Hughes G, McCormick B. 2000. Do geographic mobility costs increase unemployment? Mimeo, University of Southampton.

Im K, Pesaran H, Shin Y. 1997. Testing for unit roots in heterogeneous panels. Mimeo, Cambridge University.

Jackman R, Layard R, Savouri S. 1991. Mismatch: a framework for thought. In Mismatch and Labour Mobility, Padoa-Scioppa F (ed.). Cambridge University Press: Cambridge.

Jackman R, Savouri S. 1992. Regional migration versus regional commuting: the identification of housing and employment flows. Scottish Journal of Political Economy 39: 272-287.

Layard R, Nickell S. 1986. Unemployment in Britain. Economica 53: S121-S170.

Layard R, Nickell S, Jackman R. 1991. Unemployment: macroeconomic performance and the labour market. Oxford University Press: Oxford.

McCormick B. 1997. Regional unemployment and labour mobility in the UK. European Economic Review 41: $581-589$.

Minford P, Peel M, Ashton P. 1987. The Housing Morass. Institute of Economic Affairs: London.

Muellbauer J, Murphy A. 1994. Explaining regional house prices in the UK. Mimeo, Nuffield College, Oxford University.

Muellbauer J, Murphy A. 1997. Booms and busts in the UK housing market. Economic Journal 107: $1701-1727$.

Oswald A. 1998. High unemployment and high home-ownership. Mimeo, Economics Department, Warwick University.

Pesaran MH, Shin Y, Smith R. 1999. Pooled mean group estimation of dynamic heterogeneous panels. Journal of the American Statistical Association 94: 621-634.

Phelps E. 1968. Money-wage dynamics and labor-market equilibrium. Journal of Political Economy 76: $678-711$.

Phillips A. 1958. The relation between unemployment and the rate of change of money wage rates in the United Kingdom, 1861-1957. Economica 48: 345-363. 
Pissarides C, McMaster I. 1990. Regional migration, wages and unemployment: empirical evidence and implications for policy. Oxford Economic Papers 42: October, 812-831.

Sargan D. 1964. Wages and prices in the United Kingdom: a study in econometric methodology. In Econometric Analysis for National Economic Planning, Hart P, Mills G, Whitaker J (eds). Butterworth \& Co: London.

Sargan D. 1971. A study of wages and prices in the UK, 1949-68. In The Current Inflation, Johnson H, Nobag A (eds). Macmillan: London.

Sargan D. 1980. A model of wage-price inflation. Review of Economic Studies 47: 91-112.

White H. 1980. A heteroscedasticity-consistent covariance matrix estimator and a direct test for heteroscedasticity. Econometrica 48: 817-838.

Zellner A. 1962. An efficient method of estimating seemingly unrelated regressions and tests of aggregation bias. Journal of the American Statistical Association 57: 500-509. 